POLIIICAL ECONOMY RESEARCH INSIITUTE

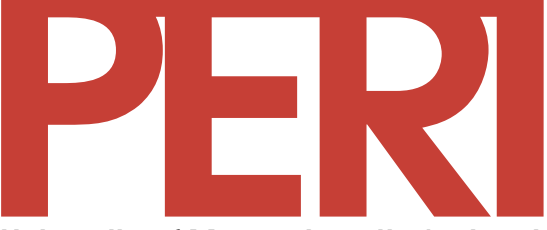

University of Massachusetts Amherst

\title{
Africa's Debt: Who Owes Whom?
}

\author{
James K. Boyce \\ Léonce Ndikumana
}

2002

10th floor Thompson Hall University of Massachusetts Amherst, MA, 01003-7510 Telephone: (413) 545-6355 Facsimile: (413) 545-2921

Email:peri@econs.umass.edu Website:

http://www.umass.edu/peri/

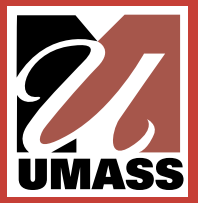




\title{
Africa's Debt: Who Owes Whom?
}

\author{
James K. Boyce and Léonce Ndikumana \\ Department of Economics and Political Economy Research Institute \\ University of Massachusetts \\ Amherst, MA 01003
}

November 22, 2002

Corresponding author:

Léonce Ndikumana

Department of Economics

University of Massachusetts

Amherst, MA 01003

Tel: (413) 545-6359

Fax: (413) 545-2921

Email: $\underline{\text { ndiku@econs.umass.edu }}$ 


\section{Sub-Saharan Africa's debt burden}

Sub-Saharan Africa includes 34 of the 42 countries classified as "Heavily Indebted Poor Countries" by the World Bank. The debt burden forces these countries to divert scarce resources from basic necessities, such as health and education, into debt service. Despite bearing these heavy social costs, African countries cannot keep up with the payments, and so they become ever more indebted.

The total debt of sub-Saharan African countries reached a staggering \$209 billion in 2001. In that year, the sub-continent borrowed $\$ 11.4$ billion, but paid $\$ 14.5$ billion in debt service $-\$ 9.8$ billion as principal repayment and $\$ 4.7$ billion as interest. As a result, the region recorded a negative 'net transfer' (new borrowing minus debt service) of $-\$ 3.1$ billion. This continued a trend of negative net transfers in the previous decade (see Figure 1).

In Sub-Saharan Africa (SSA) as a whole, debt service amounted to $3.8 \%$ of gross domestic product (GDP) in 2000. By comparison, SSA countries spent $2.4 \%$ of GDP on health. The World Bank estimates that only $55 \%$ of the people in SSA have access to clean drinking water, compared to an average of $76 \%$ for low-income countries worldwide (World Development Indicators 2002). Illiteracy rates and infant mortality rates in SSA are among the highest in the world. 
The inability of many SSA countries to meet their social needs and escape from debt is, to a large extent, a result of the fact that the borrowed funds have not been used productively. In theory, borrowing decisions are motivated by expectations of positive returns to investment financed by loans, and by expectations of higher future income to repay loans that financed consumption. In the case of most African countries, however, it appears that past borrowing was not justified by either the investment motive or the consumption-smoothing rationale. Where, then, did the borrowed money go?

\section{Debt and capital flight: Africa's revolving door}

Instead of financing domestic investment or consumption, a substantial fraction of the borrowed funds was captured by African political elites and channeled abroad in the form of capital flight. Through this 'revolving door,' public external debts (contracted via borrowing by African governments or by private firms with government guarantees) were transformed into private external assets.

Estimates of capital flight from SSA indicate that the sub-continent experienced dramatic financial hemorrhage over the past three decades. In a study of 30 SSA countries, we estimate total capital flight for the period 1970-1996 to have been about $\$ 187$ billion in 1996 dollars (Ndikumana and Boyce 2002; see also Boyce and Ndikumana 2001).

Including interest earnings, the stock of capital flight for the sample stood \$274 billion, equivalent to $145 \%$ of the total debt owed by the same group of countries in 1996 . In other words, we find that SSA is a net creditor to the rest of the world in the sense that 
external assets, as measured by the stock of capital flight, exceed external liabilities, as measured by the stock of external debt. The difference is that while the assets are in private hands, the liabilities are the public debts of African governments.

Statistical evidence reveals that external borrowing was the single most important determinant of both the timing and magnitude of capital flight from SSA. Over the 19701996 period, roughly 80 cents on every dollar borrowed by SSA countries flowed back out as capital flight in the same year (Ndikumana and Boyce 2002). This suggests that external borrowing directly financed capital flight. Moreover, every dollar added to a country's total debt generated roughly 3.5 cents of capital flight per year in subsequent years, suggesting that capital flight was also a response to the deteriorating economic environment associated with rising debt burdens.

The mechanisms by which national resources are channeled abroad as capital flight include embezzlement of borrowed funds, kickbacks on government contracts, trade misinvoicing, misappropriation of revenues from state-owned enterprises, and smuggling of natural resources. Countries with rich endowments of natural resources, especially when headed by corrupt regimes, have experienced large-scale capital flight. During his 32-year reign in the Congo, former president Mobutu accumulated massive wealth through the diversion of borrowed funds, foreign aid, and revenues from the state-owned mineral companies (Ndikumana and Boyce 1998). His personal assets reportedly peaked in the mid-1980s at $\$ 4$ billion (Burns et al. 1997). In Nigeria, the leaders of successive military regimes systematically embezzled oil revenues for their personal enrichment, 
often with the complicity of multinational corporations. In April 2002, an out-of-court settlement in Switzerland ordered the return to Nigeria of more than $\$ 1$ billion in frozen assets of former dictator Sani Abacha and his family (International Herald Tribune, 2002). A recent IMF investigation reveals that in the past five years up to $\$ 4$ billion is unaccounted for in government finances in Angola (Pearce 2002).

Responsibility for the diversion of borrowed funds falls not only on past African governments, but also on their creditors, including private bankers as well as bilateral and multilateral institutions. Knowingly or unknowingly, these creditors financed the accumulation of private assets with their loans. In many cases, creditors continued to pour loans in the hands of corrupt regimes, despite ample evidence that these funds were not being used for legitimate purposes. Sound banking practice would have dictated a moratorium on lending to such governments. Failure to halt lending suggests either that creditors were shielded from losses or that they were pursuing other objectives. On the one hand, private lenders were shielded from risk by guarantees provided by governments and international institutions. All too often, these guarantees encouraged irresponsible lending. On the other hand, official creditors continued to lend to client regimes for political and strategic reasons. The Mobutu regime and the military regimes in Nigeria are examples of instances where lending supported dictatorships in the region.

\section{What is to be done?}


African countries must not only overcome the debt payment crisis, but also design strategies to prevent borrowed funds from being squandered in the future.

Since the early 1980s, a series of strategies have been proposed to alleviate the external debt burden in developing countries. Traditional mechanisms of rescheduling debt payments have failed, as these only amount to postponing the debt burden and actually result in an increase in future debt stocks. The debt forgiveness initiatives that were initiated in 1988 at the G-7 meetings in Toronto, which provided for various arrangements aimed at reducing the present value of debt outstanding, also failed to resolve the debt problem. The external position of African countries continued to deteriorate as indicated by the decline in net transfers on debt depicted in Figure 1. The Highly-Indebted Poor Countries (HIPC) debt-relief initiative launched in 1996 by the World Bank and other donors is a step in the right direction, in that it provides for larger reductions in the present value of debt. Yet this strategy too has proven to be insufficient for reducing the debt burden, due to the slow pace of delivery of relief by donors and the slow progress of debtor countries in meeting the often-stringent conditions for qualification. The volume of debt relief remains low compared to total liabilities of African countries and their development needs.

One effective strategy for ending the debt crisis in African countries would be the complete cancellation of all debts. This would release resources now drained by debt service for reallocation to socially productive investment programs. While debt cancellation has been advocated by a number of non-governmental organizations, it 
seems unlikely to happen in the foreseeable future. Creditors are unwilling to set a precedent for across-the-board write-offs, and SSA governments are unwilling to risk the reprisals that might follow from outright repudiation of debt. Moreover, even if the debt slate could be wiped clean at a single stroke and lending were then to resume, in the absence of systematic changes in the practices of borrowers and lenders this would simply clear the way for another spin of the revolving door, setting the stage for a new debt crisis in years to come.

An alternative strategy is for African countries to selectively repudiate past loans, invoking the doctrine of "odious debt" in international law as well as historical precedents. At the end of the $19^{\text {th }}$ century, the United States government repudiated the external debt owed by Cuba after seizing the island in the Spanish-American war. The U.S. authorities did so on the grounds that Cuba's debt had not been incurred for the benefit of the Cuban people, that it had been contracted without their consent, and that the loans had helped to finance their oppression by the Spanish colonial government. For similar reasons, much of the debt of SSA can today be termed 'odious'.

Well-functioning credit markets require that creditors bear the consequences of imprudent lending. The notion that creditors should always be repaid, regardless of how and to whom they lend, is indefensible. The logic of sound banking suggests that current and future African governments should accept liability for only those portions of public debts incurred by past regimes that were used to finance bona fide domestic investment or public consumption. By invoking the doctrine of odious debt, they could selectively 
repudiate liability for those portions of the debt for which no such uses can be demonstrated.

Application of this strategy of selective repudiation faces two potential practical problems. The first problem is to determine who should bear the burden of proof in identifying which portions of past debts are "odious". The second is the risk of credit rationing against African countries that choose to repudiate debt, even if they do so selectively. Given the evidence of widespread capital flight fueled by external borrowing, African governments can insist that creditors have the responsibility of establishing that their loans were used for bona fide purposes. Following this logic, SSA governments could inform their creditors that outstanding debts will be treated as legitimate if, and only if, the real counterparts of the borrowing can be identified. If the creditors can document where the money went, and show that it benefited the citizens of the borrowing country via investment or consumption, then the debt will be accepted as a bona fide external obligation of the government. If, however, the fate of the borrowed money cannot be traced, then the present African governments must infer that it was diverted into private pockets, and quite possibly into capital flight. In such cases, the liability for the debt should lie not with the government, but with the private individuals whose personal fortunes are the real counterpart of the debt.

Some may worry that even selective repudiation is risky, because "Africa can ill afford to incur the wrath of the hand that feeds it" (Donnelly 2002). But the question today is: Whose hand is feeding whom? In recent years, resources flowed from Africa to Western 
countries, rather than the reverse, as indicated by the negative net transfers and massive capital flight. Africa has been 'feeding' its creditors. In the short run, the savings from halting service payments on odious debts therefore are likely to outweigh any losses from credit rationing. And in the long run, selective debt repudiation will benefit lenders as well as African countries. By inducing more responsible lending practices, the threat of selective repudiation ultimately will result in fewer losses due to default and greater efficiency in the allocation of resources by the international financial system. Indeed, if lenders apply stricter criteria with respect to the uses to which their loans are put, this will be a desirable change from the standpoint of most citizens in the borrower countries. Whatever the short-run costs of selective repudiation, it is a win-win solution for both lenders and borrowers in the long run.

In addition to greater accountability on the creditor side, it is equally important that debtor countries establish mechanisms of transparency and accountability in their own decision-making processes with regard to foreign borrowing and the management of borrowed funds. In the absence of debt cancellation or repudiation, the burden of debt repayment ultimately lies with the population of the debtor countries. It is appropriate, therefore, to require debtor governments to provide full information to the public as well as to their creditors, and to ensure public representation in the management of public debt. In future years, greater accountability on the part of both borrowers and creditors will be needed to prevent repeated cycles of external borrowing, capital flight, and financial distress. 


\section{References}

Boyce, James K. (1992) “The revolving door? External debt and capital flight: A Philippine case study," World Development, 20 (3), 335-345.

Boyce, James K. and Léonce Ndikumana (2001). "Is Africa a net creditor? New estimates of capital flight from severely indebted Sub-Saharan African countries, 1970-1996," Journal of Development Studies, 38(2), 27-56.

Burns, Jimmy, Michael Homan, and Mark Huband (1997) "How Mobutu build up to \$4 bn fortune: Zaire’s dictator plundered IMF loans,” Financial Times 12 May 1997.

Donnelly, John (2002) "A bold proposal for poor African nations: Forget the debt," Boston Globe, 4 August 2002.

International Herald Tribune (2002) "Ex-dicator's family to pay back Nigeria," 18 April 2002, p. 3.

Ndikumana, Léonce and James K. Boyce (1998) “Congo's odious debt: External borrowing and capital flight in Zaire," Development and Change, 29(2), 195-217.

Ndikumana, Léonce and James K. Boyce (2002) "Public debts and private assets: explaining capital flight from sub-Saharan African Countries," University of Massachusetts, Department of Economics and Political Economy Research Institute, Working Paper 32 (www.umass.edu/peri/pdfs/WP32.pdf). Forthcoming in World Development, January 2003.

Pearce, Justin (2002) “Angola's 'missing millions,,” BBC News, 18 October 2002.

World Bank, Global Development Finance, CDROM edition, 2002.

World Bank, World Development Indicators, CDROM edition, 2002. 


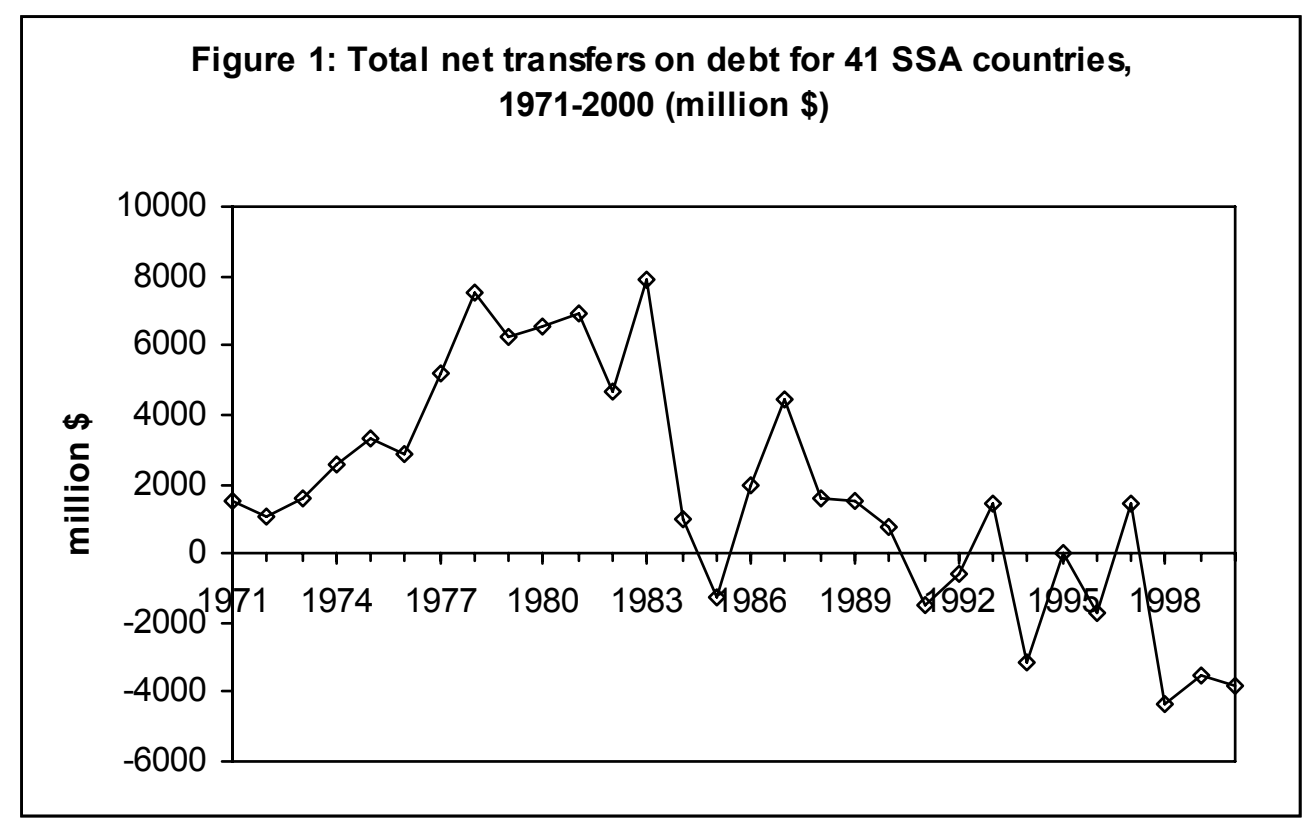

Source: Authors' computations using data from World Bank (2002), Global Development Finance. 